Review

\title{
In Vitro Degradation and Cytotoxicity of Eggshell-Based Hydroxyapatite: A Systematic Review and Meta-Analysis
}

\author{
Rohmadi Rohmadi ${ }^{1}$, Widyanita Harwijayanti ${ }^{1}$, Ubaidillah Ubaidillah ${ }^{1, *}\left(\mathbb{D}\right.$, Joko Triyono ${ }^{1}$, Kuncoro Diharjo ${ }^{1}(\mathbb{D}$ \\ and Pamudji Utomo ${ }^{2}$ \\ 1 Mechanical Engineering Department, Faculty of Engineering, Universitas Sebelas Maret, Jalan Ir. Sutami 36A, \\ Kentingan, Surakarta 57126, Indonesia; rohmadi@student.uns.ac.id (R.R.); \\ widyanitaharw@student.uns.ac.id (W.H.); jokotri5528@gmail.com (J.T.); kuncorodiharjo@ft.uns.ac.id (K.D.) \\ 2 Department Orthopaedic Traumatology, Prof Dr. R. Soeharso Orthopaedic Hospital Surakarta/Faculty of \\ Medicine, Universitas Sebelas Maret Jalan Ir. Sutami 36A, Kentingan, Surakarta 57126, Indonesia; \\ pamudji_utomo@staff.uns.ac.id \\ * Correspondence: ubaidillah_ft@staff.uns.ac.id
}

check for updates

Citation: Rohmadi, R.; Harwijayanti, W.; Ubaidillah, U.; Triyono, J.; Diharjo, K.; Utomo, P. In Vitro Degradation and Cytotoxicity of Eggshell-Based Hydroxyapatite: A Systematic Review and Meta-Analysis. Polymers 2021, 13, 3223. https://doi.org/ $10.3390 /$ polym 13193223

Academic Editor: Geoffrey R. Mitchell

Received: 11 August 2021

Accepted: 17 September 2021

Published: 23 September 2021

Publisher's Note: MDPI stays neutral with regard to jurisdictional claims in published maps and institutional affiliations.

Copyright: (c) 2021 by the authors. Licensee MDPI, Basel, Switzerland. This article is an open access article distributed under the terms and conditions of the Creative Commons Attribution (CC BY) license (https:// creativecommons.org/licenses/by/ $4.0 /)$.
Abstract: Objective: This review focuses on the in vitro degradation of eggshell-based hydroxyapatite for analyzing the weight loss of hydroxyapatite when applied in the human body. Cytotoxicity tests were used to observe cell growth and morphological effects. A systematic review and meta-analysis were conducted to observe the weight loss and viable cells of hydroxyapatite when used for implants. Method: Based on the Population, Intervention, Comparison, and Outcome (PICO) strategy, the articles used for literature review were published in English on SCOPUS, PubMed, and Google Scholar from 1 January 2012 to 22 May 2021. Data regarding existing experiments in the literature articles the in vitro degradation and cytotoxicity testing of eggshell-based hydroxyapatite determined the biocompatibility of the materials. A meta-analysis was conducted to calculate the mean difference between the solutions and soaking times used for degradation and the stem cells used for cytotoxicity. Results: From 231 relevant studies, 71 were chosen for full-text analysis, out of which 33 articles met the inclusion criteria for degradation and cytotoxicity analysis. A manual search of the field of study resulted in three additional articles. Thus, 36 articles were included in this systematic review. Significance: The aim of this study was to highlight the importance of the biocompatibility of eggshellbased hydroxyapatite. The weight loss and viability cells of eggshell-based hydroxyapatite showed optimum results for viable cells requirements above $70 \%$, and there is a weight loss of eggshell-based hydroxyapatite for a material implant. The meta-analysis indicated significant differences in the weight loss of eggshell-based hydroxyapatite materials with different soaking times and solutions used. The various kinds of stem cells for incubation of cultured cells in contact with a device, either directly or through diffusions with various kinds of stem cells from animals and humans, yielded viability cells above $70 \%$.

Keywords: eggshells; hydroxyapatite; degradation; cytotoxicity; meta-analysis

\section{Introduction}

Bone defects due to fractures remain a challenge for clinicians to repair. Recovery usually requires the use of synthetic biomaterials [1]. Accidents and chronic illnesses cause bone defects that do not heal on their own, so the development of more efficient treatments is needed [2]. Porous biomaterials are scaffolds that are suitable for forming bone tissue and encouraging the diffusion of nutrients and metabolites out of cells and scaffolds [3]. Scaffolds can be absorbed throughout the body of living things, and diffusion of the scaffold substance involves all bone tissues, whether they are in good health or are seriously damaged [4]. Hydroxyapatite, as a bioactive ceramic material, is the best candidate for bone tissue replacement among the variety of biomaterials [5]. Some researchers believe 
that the use of calcium from natural sources can reduce the risk of health issues and leads to better cell proliferation [6].

Millions of tons of shell waste (seashells, eggshells, etc.) are discarded after their contents are consumed as food $[7,8]$. Shell waste is a substantial source of calcium because most of the content contained in this material is calcite $\left(\mathrm{CaCO}_{3}\right)$ [9]. However, some marine species, such as oysters, are in danger of extinction, and most of these species have a slow growth rate. Thus, the selection of new alternative materials that are renewable, inexpensive, and easy to locate is highly recommended [10]. An important process is recycling waste into useful products. Eggshells are one of the sources of organic shell waste that are disposed of daily [11]. Development of the method for converting eggshell into hydroxyapatite is very important. Eggshells form approximately $11 \%$ of the total egg weight, consisting of $94 \%$ calcium carbonate $\left(\mathrm{CaCO}_{3}\right), 1 \%$ calcium phosphate $\left(\mathrm{Ca}_{3}\left(\mathrm{PO}_{4}\right)_{2}\right)$, and $4 \%$ organic matter [11-15]. Eggshells also contain many trace elements, such as $\mathrm{Na}$, $\mathrm{Mg}$, and Sr, resembling the bone matrix in humans [16].

Hydroxyapatite is a hydrated calcium phosphate from the mineral group of apatite. Its chemical formula is $\mathrm{Ca}_{10}\left(\mathrm{PO}_{4}\right)_{6}(\mathrm{OH})_{2}$ and it has a Ca/P ratio of $1.67[8,17,18]$. HA is a compound that has a hexagonal structure with white solids [19]. Because it has biocompatibility, bioactivity [20-22] and significant osteoinductivity [23], hydroxyapatite has been widely used as a bone substitute to fill bone defects, such as matrix scaffolding for tissue engineering [24] and as a coating on biomedical implants [20]. In biomedical applications, biomaterials must have reliable biocompatibility capabilities [25]. Biomaterials should not release any toxins or produce harmful reactions in the human body. Cytotoxicity is related to the degradation process of biomaterials, which can stimulate or inhibit the metabolism of cultured stem cells [26]; biomaterial degradation is affected by porous size and porous interconnectivity [27].

Ganesan et al. soaked hydroxyapatite in phosphate buffer saline (PBS) to evaluate in vitro degradation by measuring the weight loss of eggshell-based hydroxyapatite [27]. Kumar et al. performed a cytotoxicity test on hydroxyapatite using mouse fibroblast 3T3-L1 cells with variable observation times [20]. Horta et al. investigated eggshell-based hydroxyapatite cells with $98.9 \%$ viability that were cultured in dental pulp stem cells (DPSCs) for $24 \mathrm{~h} \mathrm{[26].} \mathrm{Both} \mathrm{in} \mathrm{vitro} \mathrm{degradation} \mathrm{and} \mathrm{cytotoxicity} \mathrm{tests} \mathrm{were} \mathrm{carried} \mathrm{out} \mathrm{to}$ determine the biocompatibility of the materials. However, meta-analyses of the in vitro degradation and cytotoxicity from eggshell-based hydroxyapatite are limited, and also the effects of soaking time variations, solutions used, cultured stem cells, and the influence of elements added to the composites in the existing published literature may not yet be displayed.

The aim of this study was to present a systematic review and meta-analysis of studies that have investigated the in vitro degradation and cytotoxicity of eggshell-based hydroxyapatite. This meta-analysis was designed to determine the effects of soaking time and solutions used for the degradation of eggshell-based hydroxyapatite and to explore the influence of different viability stem cells and the morphology of the eggshell-based hydroxyapatite that are described in published results.

\section{Materials and Methods}

\subsection{Study Design}

This systematic review and meta-analysis were performed according to the PRISMA (Preferred Reporting Items for Systematic Reviews and Meta-Analysis) guidelines. The PICO strategy involved the following:

- Population-biological evaluation, including in vitro degradation and cytotoxicity test;

- Intervention- medical implants;

- Comparison - soaking times and solutions used for degradation testing, together with different stem cells cultured for cytotoxicity testing;

- Outcomes-effects of the in vitro degradation and cytotoxicity test results to highlight the biocompatibility of eggshell-based hydroxyapatite. 


\subsection{Information Sources}

The search for articles was carried out in the SCOPUS, PubMed, and Google Scholar databases. All the articles were published in English between 1 January 2012 and 22 May 2021. After screening based on the inclusion criteria for degradation and cytotoxicity analysis for each article, they were all imported to Mendeley Desktop. The articles are focused on eggshells as a source of hydroxyapatite, and also mixing the shells with other materials, such as polycaprolactone, rice husk ash, selenium (Se), chitosan, silicon, hair keratin, and jellyfish collagen. To complement the electronic search, a manual search was conducted in the following principal periodicals specific to the field: International Journal of Applied Ceramic Technology, Journal of Materials Science, Materials in Medicine, International Journal of Nanomedicine, Journal of the American Ceramic Society, Ceramics International, Materials Science and Engineering C, Biomedical Materials, Composites Part B, Journal of Sol-Gel Science and Technology, Colloids and Surfaces B: Biointerfaces, Nanomaterials, Materials Research, Chemistry Select, Journal of Biomedical Materials Research: Part A, Journal of International Oral Health, ACS Biomaterials Science and Engineering, Bulletin of Material Science, Polymers, Journal of Biosystems Engineering, Society for Biomaterials, International Journal of Dentistry, Royal Society for Chemistry, International Journal of Biological Macromolecules, and the Journal of Materials Research and Technology. The last search was performed on 22 May 2021.

The search terms and their combinations were "hydroxyapatite", "eggshells" and "hydroxyapatite", "eggshells" and "hydroxyapatite" and "biocompatibility", "eggshells" and "hydroxyapatite" and "degradation", "eggshells" and "hydroxyapatite", and "cytotoxicity". The title, abstract, and keywords were included in the search terms. From the three databases used, a total of 33 articles and three additional articles from manual search within the specific field were included in this systematic review.

\subsection{Inclusion and Exclusion Criteria}

Biocompatibility studies reporting on the in vitro degradation and cytotoxicity testing of eggshell-based hydroxyapatite were included. Publications were excluded if the studies included other biocompatibility testing such as bioactivity, drug delivery, antibacterial, or hemolysis testing.

\subsection{Data Extraction and Collection}

The data from the articles of interest were tabulated by compiling a spreadsheet in Excel software (Microsoft Corp., Redmond, Washington, United States). The following data were collected from the included articles: demographic information (author, journal, title, date), sample preparation and composition (eggshell-based hydroxyapatite), testing preparation (soaking times and solutions used for in vitro degradation, together with stem cells for cytotoxicity), and the results of in vitro degradation and cytotoxicity testing (weight loss, viable cells, and morphology of the materials).

\subsection{Data Analysis}

The material composition and method variability of the studies included were used for the meta-analysis. For the meta-analysis, a statistical analysis was conducted based on results from articles, including the various samples which were analyzed for soaking times, solutions used, and different stem cells used for culturing. The weight losses of the materials were plotted on graphs. The results for various stem cells are presented in Table 2. The template of viable cells for each testing method was copied from each article and is presented in Tables 3 and 4. In addition, analyses were performed to assess the different results from the cytotoxicity testing methods used for eggshell-based hydroxyapatite. The data are displayed in the form of qualitative and quantitative results. 


\section{Results}

\subsection{Study and Information Selection}

Out of 71 relevant article titles collected from SCOPUS, PubMed, and Google Scholar, only 36 were included after screening the title, abstract, and content for in vitro degradation and cytotoxicity testing for the biocompatibility of eggshell-based hydroxyapatite. The articles came from several countries, such as India [11,14,27-40], Bangladesh [41,42], China [43], Korea [25,44,45], Turkey [46-48], Thailand [49,50], Brazil [26], Italy [51], USA [52], Romania [2], Vietnam [53,54], Colombia [55], and Egypt [56]. The study selection of the articles included in the systematic review is shown in Figure 1. The articles were published from 1 January 2012 to 22 May 2021.

Out of 71 articles collected for full-text analysis from SCOPUS, PubMed, and Google Scholar, only 36 studies were included after applying the inclusion and exclusion criteria. Three studies were excluded because the results of the cytotoxicity tests were not specific and used different methods of measurement. During 2012-2016, only 6 articles were published, resulting in a mean of 1.2 articles per year. In the next five years (2017-2021), the field rapidly grew, and a total of 30 articles were published in this period (Figure 2).

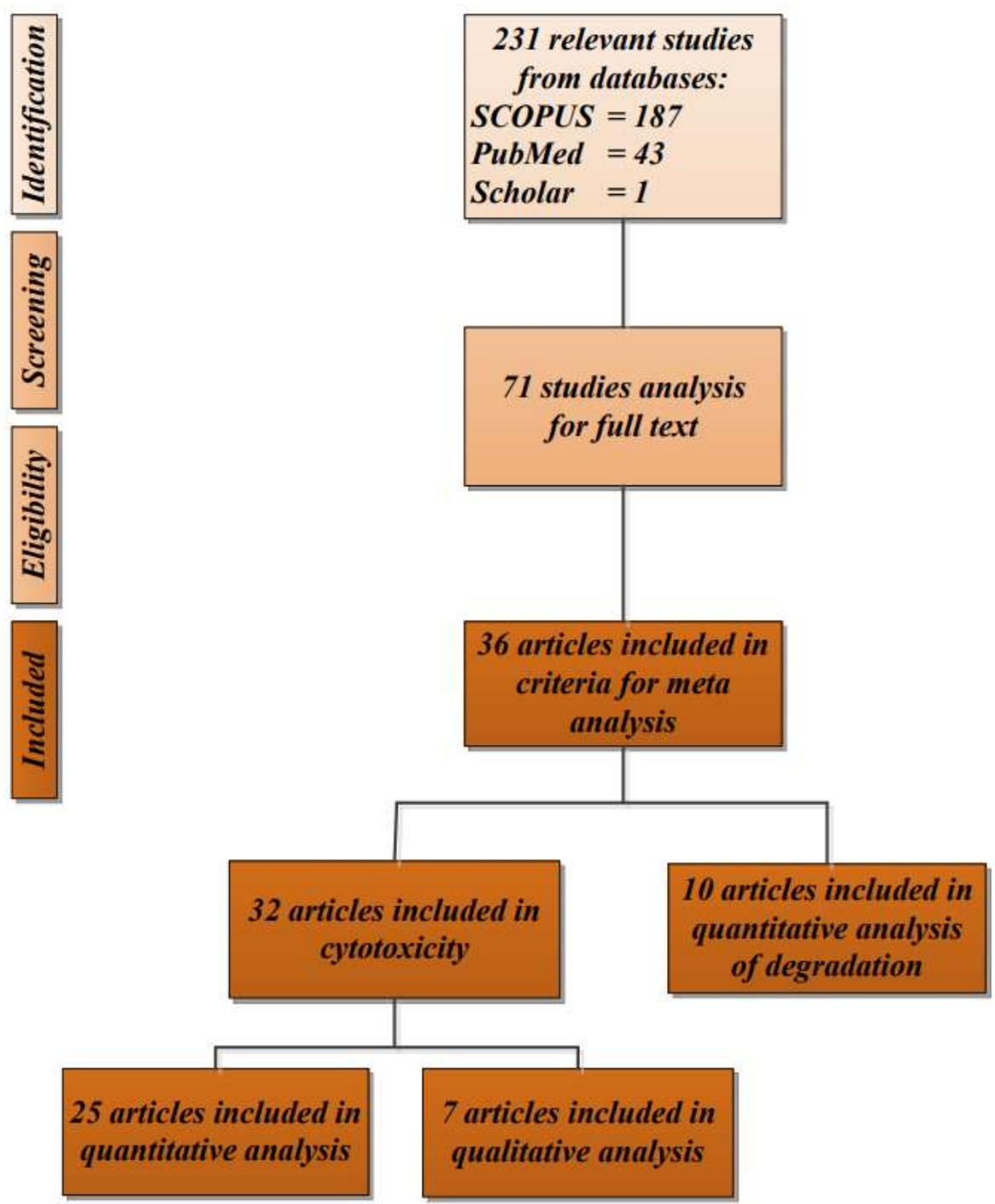

Figure 1. Flow diagram of the study selection of the articles included in the systematic review. 


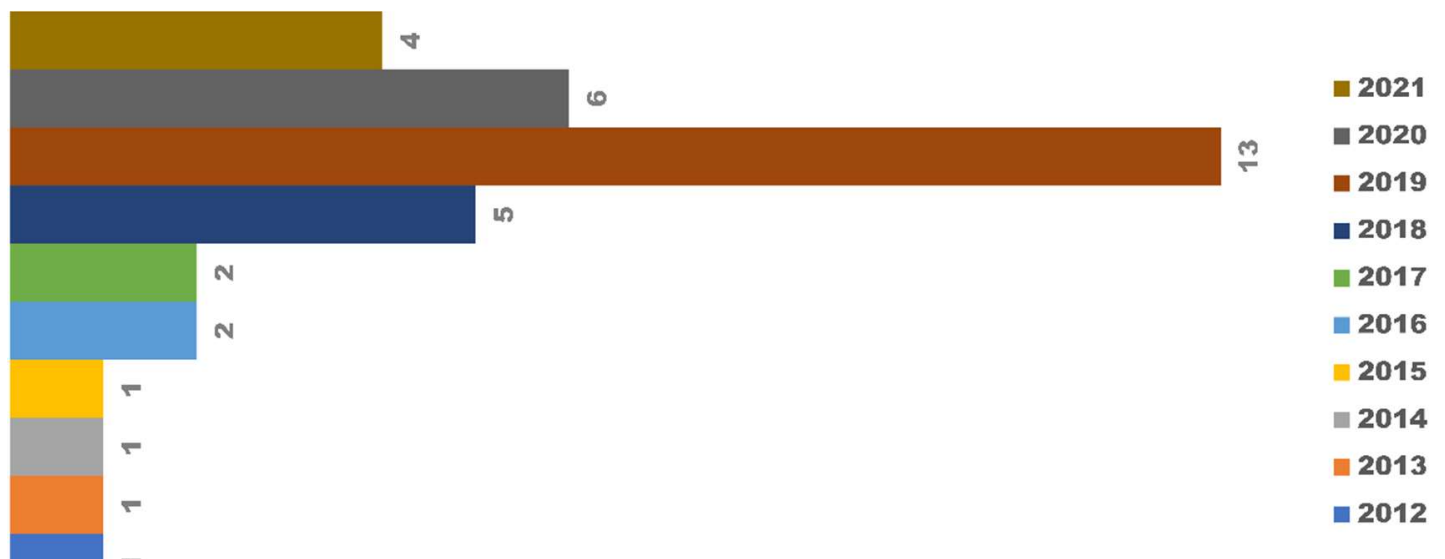

NUMBER OF ARTICLES

Figure 2. Articles published on the subject of in vitro degradation and cytotoxicity testing of eggshell-based hydroxyapatite from 1 January 2012 to 22 May 2021.

\subsection{Qualitative Analysis}

All the articles included pertain to in vitro degradation and cytotoxicity tests of eggshell-based hydroxyapatite. The results of the cytotoxicity testing consisted of two types: quantitative and qualitative. The results of the quantitative testing are discussed in Section 3.3. The qualitative results are displayed in the Figure 3, showing the appearance of the surface morphology of the materials. Of the articles included in this review, the qualitative results involved seven cytotoxicity tests, from the articles of $[32,34,38,44,48,51,52]$.

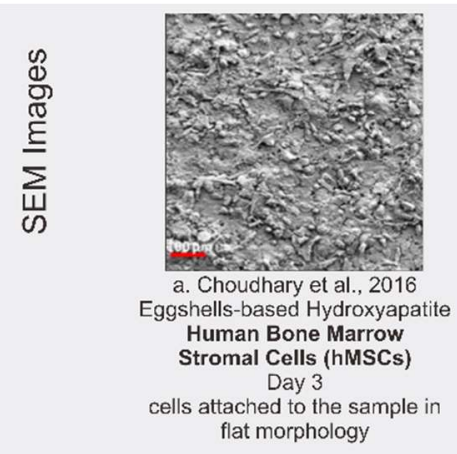

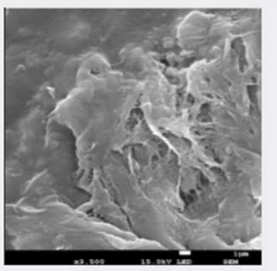

b. Holloman et al., 2020

Eggshells-based Hydroxyapatite Human Osteoblast Cells

Day 3 and ruffling of cytoplasm

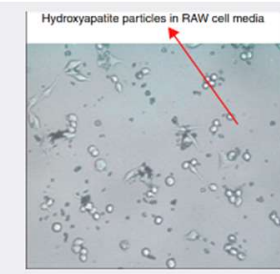

c. Mondal et al., 2012 Eggshells-based Hydroxyapatite RAW Cell Line (mouse) Day 3

No dead cells in the culture vessels

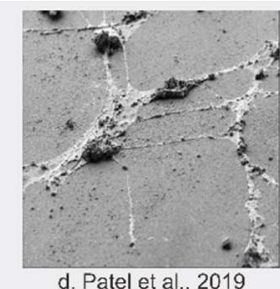

d. Patel et al., 2019 Eggshells-based Hydroxyapatite mesenchymal stem cells (BMSCs) Day 3
the cells adhered to Hap surface

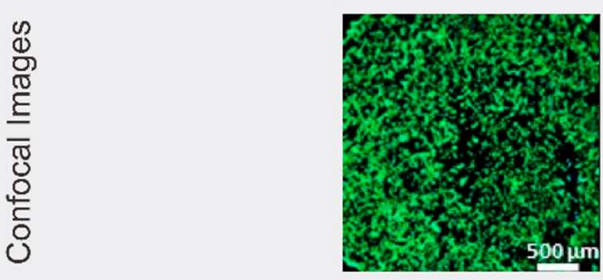

e. Cestari et al., 2021 Eggshells-based Hydroxyapatite Human Lung Fibroblasts Cell Line (MRC5) Day 3

improvement in cell adhesion pattern with elongated cell morphology

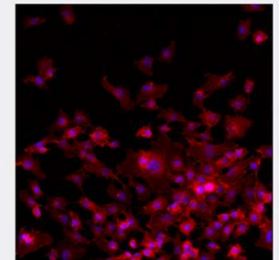

f. Oral et al., 2020 Eggshells-based Hydroxyapatite (spherical) Bone Cells (hFOB) cells cultured with ellipsoidal and spherical particles exhibit higher stem cells densities

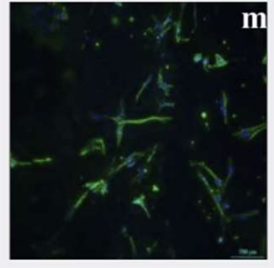

g. Roopavath et al., 2019 Eggshells-based Hydroxyapatite Mesenchymal Stem Cells (ADSCs) stem cell were proliferating and invading into the micropores of the scaffolds

Figure 3. SEM images (a-d) and confocal images (e-g) of cytotoxicity tests with different stem cells for cultures. 


\subsection{Meta-Analysis}

Eggs are a major source of food consumed by people worldwide [12]. There are different eggshell types used to obtain hydroxyapatite, such as chicken eggshell [57-59], avian eggshell [13], and duck eggshell [60]. Chicken eggshells are the most abundant raw material used to produce hydroxyapatite [57]. The shape and crystalline structure of hydroxyapatite play important roles in mediating cellular behaviors and/or tissue functions in human bones [25]. There are different techniques for obtaining hydroxyapatite, such as the wet precipitation method [61,62], sol-gel method [4], hydrothermal method [18], solid-state method [10,14], microwave irradiation [11], and the sonochemical method [37]. In the case of bone regeneration, scaffolds must possess other important properties, such as osseointegration and osteoconduction. Their main role is to facilitate the formation of an extracellular matrix [2]. In vitro biological tissue formation is have potential to be used as replacement for animals along with pharmacological and toxicological screening, and as a replacement tissue for use in clinical applications [63].

For in vitro degradation and cytotoxicity tests, a meta-analysis was performed using experimental data from 36 literature articles, and the results are described in Tables 1 and 2. Table 1 shows the results obtained from studies reporting on solutions and soaking times used to observe the weight loss of the eggshell-based hydroxyapatite compositions. Weight loss analysis is affected by the number of days and solutions used during the soaking process, along with the composition of the material. Weight loss can also be observed by the purity and shape of the hydroxyapatite powder, microstructure of hydroxyapatite [31], the condition of the human body, or the solutions used to adjust to the $\mathrm{pH}$ of the human body [27]. The observed porosity of the microstructure hydroxyapatite affects the absorption of the solution used due to the surface area of eggshell-based hydroxyapatite [27]. The formation of a secondary phase from hydroxyapatite to $\beta$-TCP also affects the releasing ion [27]. The percentage of weight loss is given by the result obtained from degradation testing. A degradation test is carried out by soaking the materials using a solution with the same $\mathrm{pH}$ as the human body. Samples are immersed in solutions and incubated at $37^{\circ} \mathrm{C}-$ the typical human body temperature-for a period of time, between 7 until 28 days [27]. The solutions are refreshed at certain times, after $1 \mathrm{~h}$ for the first $5 \mathrm{~h}$, and then every $24 \mathrm{~h}$ after first time soaking, and on the 7th day the samples are removed and dried [35]. The samples are weighed and the percentage of weight loss is then calculated. Soaking of the materials in solutions with a $\mathrm{pH}$ equal to the $\mathrm{pH}$ of the human body is the initial simulation of the implant material being placed into the human body.

Table 1. In vitro degradation test data based on various soaking solutions and times.

\begin{tabular}{|c|c|c|c|c|c|}
\hline \multirow{2}{*}{ No } & \multirow{2}{*}{ Authors } & \multirow{2}{*}{ Year } & \multirow{2}{*}{ Sample Composition } & \multicolumn{2}{|c|}{ Soaking } \\
\hline & & & & Solutions & Days \\
\hline 1 & Zhang et al. [31] & 2020 & $\begin{array}{l}\text { Eggshell-based hydroxyapatite/ } \\
\text { rice husk ash (RHA) + zirconia (Zr) }\end{array}$ & TBS & 21 \\
\hline 2 & Jayasree et al. [33] & 2019 & $\begin{array}{l}\text { Eggshell-based hydroxyapatite cement/ } \\
\text { brushite cement }\end{array}$ & PBS & 28 \\
\hline 3 & Palakurthy et al. [29] & 2019 & Eggshell-based hydroxyapatite & TBS & 21 \\
\hline 4 & Trakoolwannachai et al. [49] & 2019 & $\begin{array}{l}\text { Eggshell-based hydroxyapatite/ } \\
\text { polycaprolactone (PCL) }\end{array}$ & PBS & 14 \\
\hline 5 & Ganesan et al. [27] & 2019 & Eggshell-based hydroxyapatite & PBS & 28 \\
\hline 6 & Palakurthy et al. [30] & 2019 & $\begin{array}{l}\text { Eggshell-based hydroxyapatite/ } \\
\text { rice husk ash (RHA) }\end{array}$ & TBS & 21 \\
\hline 7 & Palakurthy et al. [28] & 2018 & $\begin{array}{c}\text { Eggshell-based hydroxyapatite/ } \\
\text { rice husk ash (RHA) }\end{array}$ & TBS and SBF & 21 \\
\hline
\end{tabular}


Table 1. Cont.

\begin{tabular}{|c|c|c|c|c|c|}
\hline \multirow{2}{*}{ No } & \multirow{2}{*}{ Authors } & \multirow{2}{*}{ Year } & \multirow{2}{*}{ Sample Composition } & \multicolumn{2}{|c|}{ Soaking } \\
\hline & & & & Solutions & Days \\
\hline 8 & Wang et al. [43] & 2018 & $\begin{array}{l}\text { Eggshell-based hydroxyapatite/ } \\
\text { selenium (Se) }\end{array}$ & PBS & 7 \\
\hline 9 & Naga et al. [56] & 2018 & $\begin{array}{l}\text { Eggshell-based hydroxyapatite/ } \\
\text { zirconia-toughened alumina (ZTA) }\end{array}$ & SBF & 28 \\
\hline 10 & Sundaram et al. [35] & 2015 & $\begin{array}{l}\text { Eggshell-based hydroxyapatite/ } \\
\text { polycaprolactone (PCL) }\end{array}$ & PBS & 7 \\
\hline
\end{tabular}

Table 2. In vitro cytotoxicity test data based on various stem cells used for the culture.

\begin{tabular}{|c|c|c|c|c|}
\hline No & Author & Year & Sample Composition & Various Stem Cells \\
\hline 1 & Jahangir et al. [41] & 2021 & $\begin{array}{l}\text { Eggshell-based hydroxyapatite; fish } \\
\text { bone-based hydroxyapatite; fish scale-based } \\
\text { hydroxyapatite }\end{array}$ & $\begin{array}{l}\text { African Green Monkey } \\
\text { Kidney Epithelial Cells }\end{array}$ \\
\hline 2 & Tram et al. [54] & 2021 & Eggshell-based hydroxyapatite & $\begin{array}{l}\text { Osteoblastic-Cell Line } \\
\text { MC3T3-E1 }\end{array}$ \\
\hline 3 & Cestari et al. [51] & 2021 & $\begin{array}{l}\text { Eggshell-based hydroxyapatite; cuttlefish } \\
\text { bone-based hydroxyapatite; mussel } \\
\text { shell-based hydroxyapatite }\end{array}$ & $\begin{array}{l}\text { Human Lung Fibroblast Cell } \\
\text { Line (MRC5) }\end{array}$ \\
\hline 4 & Sultana et al. [42] & 2021 & Eggshell-based hydroxyapatite & $\begin{array}{l}\text { African Green Monkey } \\
\text { Kidney Cell }\end{array}$ \\
\hline 5 & Zhang et al. [31] & 2020 & $\begin{array}{l}\text { Eggshell-based hydroxyapatite/ } \\
\text { rice husk ash (RHA) }\end{array}$ & $\begin{array}{l}\text { Human Osteosarcoma } \\
\text { MG-63 Cells }\end{array}$ \\
\hline 6 & Horta et al. [26] & 2020 & Eggshell-based hydroxyapatite & $\begin{array}{l}\text { Dental Pulp Stem Cells } \\
\text { (DPSCs) }\end{array}$ \\
\hline 7 & Holloman et al. [52] & 2020 & $\begin{array}{l}\text { Eggshell-based hydroxyapatite; littleneck } \\
\text { clam shell-based hydroxyapatite; quahog } \\
\text { clam shell-based hydroxyapatite }\end{array}$ & Human Osteoblast Cells \\
\hline 8 & Muthu et al. [40] & 2020 & Eggshell-based hydroxyapatite & $\begin{array}{l}\text { L929 Cell Line (mouse } \\
\text { fibroblast) }\end{array}$ \\
\hline 9 & Neacsu et al. [2] & 2020 & $\begin{array}{c}\text { Membrane Eggshell-based } \\
\text { hydroxyapatite/bovine/chitosan/gel }\end{array}$ & $\begin{array}{l}\text { GM0047 Amniotic Fluid } \\
\text { Stem Cell Line }\end{array}$ \\
\hline 10 & Oral et al. [48] & 2020 & Eggshell-based hydroxyapatite & Human Bone Cell (hFOB) \\
\hline 11 & Ingole et al. [37] & 2019 & Eggshell-based hydroxyapatite & $\begin{array}{l}\text { Human Bone-Derived } \\
\text { Osteoblasts (hFOB) }\end{array}$ \\
\hline 12 & Prieto et al. [55] & 2019 & $\begin{array}{l}\text { Eggshell-based hydroxyapatite/ } \\
\text { silicon (Si)/PLGA }\end{array}$ & $\begin{array}{l}\text { Human Osteoblast Cell } \\
\text { Systems }\end{array}$ \\
\hline 13 & Li et al. [25] & 2019 & Eggshell-based hydroxyapatite & $\begin{array}{l}\text { Rat Bone-Marrow-Derived } \\
\text { Mesenchymal Stem Cells }\end{array}$ \\
\hline 14 & Huang et al. [64] & 2019 & Eggshell-based hydroxyapatite and egg white & $\begin{array}{l}\text { Human Dental Pulp Stem } \\
\text { Cells (hDPSCs) }\end{array}$ \\
\hline 15 & Patel et al. [45] & 2019 & Eggshell-based hydroxyapatite & Human Osteocyte Cells \\
\hline 16 & Trakoolwannachai et al. [50] & 2019 & Eggshell-based hydroxyapatite/chitosan & $\begin{array}{l}\text { Human Osteosarcoma Cells } \\
\text { (Saos-2) }\end{array}$ \\
\hline 17 & Jayasree et al. [33] & 2019 & $\begin{array}{l}\text { Eggshell-based hydroxyapatite } \\
\text { cement/brushite cement }\end{array}$ & L6 and MG63 Cells \\
\hline
\end{tabular}


Table 2. Cont.

\begin{tabular}{|c|c|c|c|c|}
\hline No & Author & Year & Sample Composition & Various Stem Cells \\
\hline 18 & Trakoolwannachai et al. [49] & 2019 & $\begin{array}{c}\text { Eggshell-based } \\
\text { Hydroxyapatite/Polycaprolactone (PCL) }\end{array}$ & $\begin{array}{l}\text { Human Osteosarcoma Cells } \\
(\text { Saos-2) }\end{array}$ \\
\hline 19 & Ganesan et al. [27] & 2019 & Eggshell-based Hydroxyapatite & L929 Cells (mouse fibroblast) \\
\hline 20 & Patel et al. [44] & 2019 & Eggshell-based Hydroxyapatite & $\begin{array}{l}\text { Bone Marrow-Derived } \\
\text { Mesenchymal Stem Cells } \\
\text { (BMSCs) }\end{array}$ \\
\hline 21 & Roopavath et al. [32] & 2019 & Eggshell-based Hydroxyapatite & $\begin{array}{l}\text { Human Adipose-Derived } \\
\text { Mesenchymal Stem Cells } \\
\text { (ADSCs) }\end{array}$ \\
\hline 22 & Palakurthy et al. [28] & 2018 & $\begin{array}{l}\text { Eggshell-based Hydroxyapatite/ } \\
\text { Rice Husk Ash (RHA) }\end{array}$ & $\begin{array}{l}\text { Human Osteosarcoma } \\
\text { MG-63 Cells }\end{array}$ \\
\hline 23 & Nga et al. [53] & 2018 & Eggshell-based Hydroxyapatite & MEM with SBF \\
\hline 24 & Wang et al. [43] & 2018 & $\begin{array}{l}\text { Eggshell-based Hydroxyapatite/ } \\
\text { Selenium (Se) }\end{array}$ & $\begin{array}{l}\text { Whole Blood of Forty } \\
\text { Healthy Individuals }\end{array}$ \\
\hline 25 & Yilmaz et al. [47] & 2018 & $\begin{array}{c}\text { Eggshell-based } \\
\text { Hydroxyapatite/Graphite/Chitosan }\end{array}$ & MC3T3-E1 Cells \\
\hline 26 & Ingole et al. [36] & 2017 & $\begin{array}{c}\text { Eggshell-based Hydroxyapatite; commercial } \\
\text { HA }\end{array}$ & Ham's F12 \\
\hline 27 & Arslan et al. [46] & 2017 & $\begin{array}{l}\text { Eggshell-based Hydroxyapatite/Hair } \\
\text { Keratin/Jellyfish Collagen }\end{array}$ & $\begin{array}{l}\text { Human Amniotic } \\
\text { Mesenchymal Stem Cells } \\
\text { (AMSCs) }\end{array}$ \\
\hline 28 & Choudhary et al. [38] & 2016 & Eggshell-based Hydroxyapatite & $\begin{array}{l}\text { Human Bone Marrow } \\
\text { Stromal Cells (hMSCs) }\end{array}$ \\
\hline 29 & Ingole et al. [14] & 2016 & Eggshell-based Hydroxyapatite & $\begin{array}{l}\text { Human Bone-Derived } \\
\text { Osteoblasts (hFOB) }\end{array}$ \\
\hline 30 & Sundaram et al. [35] & 2015 & $\begin{array}{c}\text { Eggshell-based } \\
\text { Hydroxyapatite/Polycaprolactone (PCL) }\end{array}$ & $\begin{array}{l}\text { Fibroblast Cell Line NIH-3T3 } \\
\text { and Osteoblast Cell Line } \\
\text { MG-63 }\end{array}$ \\
\hline 31 & Kattimani et al. [39] & 2014 & Eggshell-based Hydroxyapatite & Human Osteoblast Cells \\
\hline 32 & Kumar et al. [20] & 2013 & Eggshell-based Hydroxyapatite & $\begin{array}{l}\text { 3T3-L1 cells (mouse } \\
\text { fibroblast) }\end{array}$ \\
\hline 33 & Mondal et al. [34] & 2012 & $\begin{array}{c}\text { Eggshell-based Hydroxyapatite; Fish Bone- } \\
\text { based Hydroxyapatite; Bovine Bone-based } \\
\text { Hydroxyapatite }\end{array}$ & RAW Cell Lines \\
\hline
\end{tabular}

The cytotoxicity test, one of the biological evaluation and screening tests, uses tissue cells in vitro to observe the cell growth, reproduction, and morphological effects of medical devices [25]. The in vitro cytotoxicity test uses ISO 10993-5:2009 [26]. In this work, the limitation of cytotoxicity tests was based on the direct contact test. These methods specify the incubation of cultured cells in contact with a device and/or extracts of a device directly. Cytotoxic effects can be determined by either qualitative or quantitative means. Qualitative means are appropriate for screening purposes by examining the cells microscopically using cytochemical staining and general morphology. For quantitative means, the methods used and endpoints measured in cytotoxicity determination are based on cell growth, where the number of cells are quantified by objective means. Based on ISO 10993-5:2009, reduction of cell viability by more than $30 \%$ is considered a cytotoxic effect. Table 2 shows the results obtained from studies reporting on various kinds of stem cells used for cultures and the sample compositions of hydroxyapatite. There are two quantitative results obtained from the cytotoxicity tests-optical density and cell viability. Viability cells are the number of living cells in a population [65]. Viability assays were carried out with 
cultured cells from humans or animals. A viability assay is performed by observing the optical density of the absorbance value of the materials. Optical density testing is carried out to determine the number of growing cell colonies. Cell viability is the ratio of the optical density of the treatment and control materials in percentage units. Viability cells are shown as a percentage because it compares the value of optical density treatment and optical density control from eggshell-based hydroxyapatite. The statistical significance of the difference between the control and treatment groups was evaluated using a one-way analysis of variance (ANOVA) [45]. The quantification of viable cells was evaluated with the help of fluorescence microscopy $[2,25,26]$, field emission scanning electron microscopy (FESEM) [52], and scanning electron microscopy [55]. The optical density test results from articles $[2,20,49,50]$ are displayed in Figure 4 with a comparison of the control samples and treatment material variations, which can be used to determine the value of cell viability. The test results for cell viability from the studies are shown in Tables 3 and 4. Table 3 shows viable cells using human stem cells while Table 4 shows viable cells using stem cells from various animals. Quantitative data are obtained from bar charts with standard deviation shown in the included articles.

Table 3. Results for viable cell of cytotoxicity testing using human stem cells.

\begin{tabular}{|c|c|c|c|c|c|c|c|}
\hline \multirow{2}{*}{ No. } & \multirow{2}{*}{ Author } & \multirow{2}{*}{ Year } & \multicolumn{2}{|c|}{ Materials } & \multirow{2}{*}{ Composition } & \multicolumn{2}{|r|}{ Results } \\
\hline & & & Eggshell & Composite & & Day & Viability Cells (\%) \\
\hline 1 & Palakurthy et. al. [29] & 2020 & - & $v$ & $\begin{array}{c}\text { Eggshell based } \\
\text { Hydroxyapatite/Rice Husk } \\
\text { Ash (RHA) }\end{array}$ & 2 & $>70$ \\
\hline 2 & Horta et. al. [26] & 2020 & $v$ & - & $\begin{array}{l}\text { Eggshell based } \\
\text { Hydroxyapatite }\end{array}$ & 1 & 98.9 \\
\hline 3 & Ingole et. al. [37] & 2019 & $v$ & - & $\begin{array}{l}\text { Eggshell based } \\
\text { Hydroxyapatite }\end{array}$ & 1 & $>95$ \\
\hline 4 & Prieto et. al. [55] & 2019 & - & $v$ & $\begin{array}{c}\text { Eggshell based } \\
\text { Hydroxyapatite/Silicon } \\
\text { (Si)/PLGA }\end{array}$ & 8 & $>80$ \\
\hline 5 & Huang et. al. [64] & 2019 & $v$ & - & $\begin{array}{c}\text { Eggshell based } \\
\text { Hydroxyapatite and } \\
\text { Eggwhite }\end{array}$ & 2 & $>70$ \\
\hline 6 & Patel et. al. [45] & 2019 & $v$ & - & $\begin{array}{l}\text { Eggshell based } \\
\text { Hydroxyapatite }\end{array}$ & 1 & $>90$ \\
\hline 7 & Palakurthy et. al. [29] & 2018 & - & $v$ & $\begin{array}{c}\text { Eggshell based } \\
\text { Hydroxyapatite/Rice Husk } \\
\text { Ash (RHA) }\end{array}$ & 2 & $>70$ \\
\hline 8 & Arslan et. al. [46] & 2017 & - & $v$ & $\begin{array}{c}\text { Eggshell based } \\
\text { Hydroxyapatite/Hair } \\
\text { Keratin/Jellyfish Collagen }\end{array}$ & 21 & $>90$ \\
\hline 9 & Ingole et. al. [14] & 2016 & $v$ & - & $\begin{array}{l}\text { Eggshell based } \\
\text { Hydroxyapatite }\end{array}$ & 1 & $>100$ \\
\hline 10 & Sundaram et. al. [35] & 2015 & - & $v$ & $\begin{array}{c}\text { Eggshell based Hydroxyap- } \\
\text { atite/Polycaprolactone } \\
\text { (PCL) }\end{array}$ & 7 & $>96$ \\
\hline
\end{tabular}


Table 4. Results for viable cell of cytotoxicity testing using stem cells from animals.

\begin{tabular}{|c|c|c|c|c|c|c|c|}
\hline \multirow{2}{*}{ No. } & \multirow{2}{*}{ Author } & \multirow{2}{*}{ Year } & \multicolumn{2}{|c|}{ Materials } & \multirow{2}{*}{ Composition } & \multicolumn{2}{|r|}{ Results } \\
\hline & & & Eggshell & Composite & & Day & Viability Cells (\%) \\
\hline 1 & Jahangir et. al. [41] & 2021 & $v$ & - & $\begin{array}{l}\text { Eggshell based Hydroxyapatite; } \\
\text { Fish Bone based Hydroxyapatite; } \\
\text { Fish Scales based Hydroxyapatite }\end{array}$ & 2 & $>95$ \\
\hline 2 & Tram et. al. [54] & 2021 & $v$ & - & Eggshell based Hydroxyapatite & 7 & $>70$ \\
\hline 3 & Sultana et. al. [42] & 2021 & $v$ & - & Eggshell based Hydroxyapatite & 1 & $>80$ \\
\hline 4 & Muthu et. al. [40] & 2020 & $v$ & - & Eggshell based Hydroxyapatite & 1 & $>96$ \\
\hline 5 & Jayasree et. al. [33] & 2019 & - & $v$ & $\begin{array}{l}\text { Eggshell based Hydroxyapatite } \\
\text { cement/Brushite cement }\end{array}$ & 3 & $>100$ \\
\hline 6 & Li et. al. [25] & 2019 & $v$ & - & Eggshell based Hydroxyapatite & 7 & $>80$ \\
\hline 7 & Ganesan et. al. [27] & 2019 & $v$ & - & Eggshell based Hydroxyapatite & 21 & 80 \\
\hline 8 & Yilmaz et. al. [47] & 2018 & - & $v$ & $\begin{array}{l}\text { Eggshell based Hydroxyap- } \\
\text { atite/Graphite/Chitosan }\end{array}$ & 1 & $>70$ \\
\hline 9 & Ingole et. al. [36] & 2017 & $v$ & - & $\begin{array}{c}\text { Eggshell based Hydroxyapatite; } \\
\text { HA comercially }\end{array}$ & 7 & $>95$ \\
\hline
\end{tabular}

3

Experimental $\quad$ Control

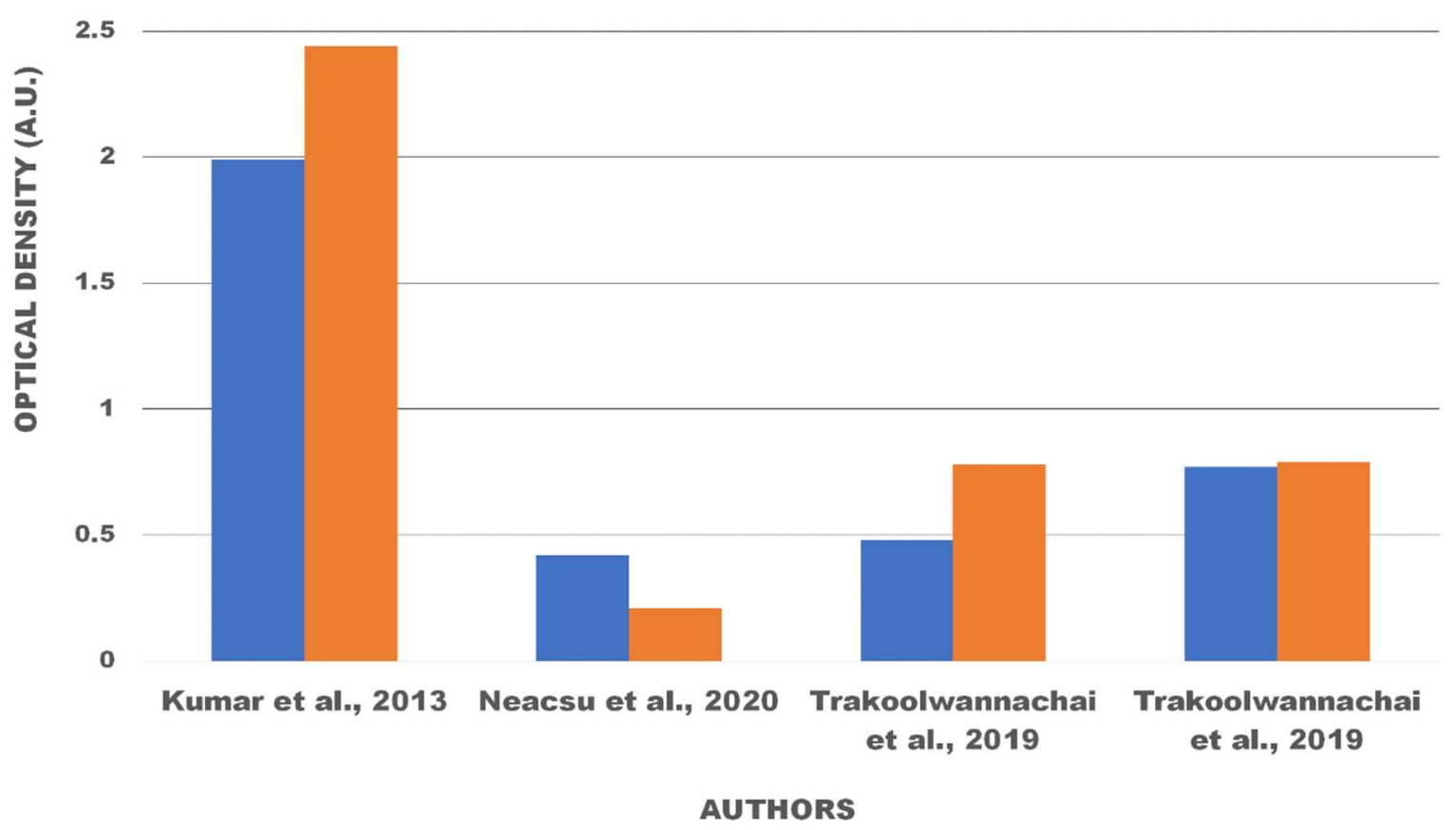

Figure 4. Optical density of materials after being cultured in various stem cells.

\section{Discussion}

As shown in Table 2, several studies have produced eggshell-based hydroxyapatite materials that were mixed with other elements. Biocompatibility and bioactivity can be affected by the presence of minor elements that are present within the environment; for example, $\mathrm{Mg}^{2+}, \mathrm{Al}^{3+}, \mathrm{Sr}^{2+}, \mathrm{Zn}^{2+}, \mathrm{K}^{+}$, and $\mathrm{Na}$ can facilitate rapid bone regeneration [52], and minor impurities do not have any adverse effect on cell attachment and proliferation [32]. 
Ions play an important role in bone biology, cell spreading, and adhesiveness. Among the different ions, other than zinc and calcium, magnesium can contribute to cell spreading and adhesion. The significant amount of magnesium obtained from eggshell-derived materials explains the cell adhesion pattern. In addition, strontium is reported to have a beneficial effect on bone structural strength and osteoblast differentiation [51].

The increasing soaking times in the in vitro degradation testing are directly linear to the degradation rate and weight loss of the materials [43]. As shown in Figure 5, the solutions used for in vitro degradation testing in the selected studies were phosphatebuffered saline (PBS) $[27,33,35,43,49]$, Tris-buffered saline (TBS) [28-31], and simulated body fluid (SBF) $[28,29]$. The third solution has the same function with ion concentrations nearly equal to human blood plasma, according to the conditions in the human body. TBS has an effective $\mathrm{pH}$ range of about 7.5-9.0, $\mathrm{PBS}$ has a $\mathrm{pH}$ range of about 6.0-8.0, and SBF has an ion concentration similar to human blood plasma. TBS does not contain ions, thus signifying the maximum solubility and minimum reprecipitation activity of the material [28].

The degradation study was evaluated by measuring the calcium ion concentration, along with $\mathrm{pH}$ variation, of the medium and weight loss of the samples [27]. As shown in Figure 6, composite hydroxyapatite/zirconia toughed alumina (ZTA) has the smallest weight loss because $\mathrm{ZrO}_{2}$ and $\mathrm{Al}_{2} \mathrm{O}$, which are the constituent elements of $\mathrm{ZTA}$, are insoluble in water, thus limiting the diffusion of the solution in the composite material [56]. With the addition of other elements, such as composite HA/polycaprolactone (PCL), which is a type of polymer [49], the percentage of weight loss is also not very significant. The degradation process only occurs on the surface of the material [49]. This is because PCL absorbs water on the surface, so that after soaking for a few days, the materials gain weight [35]. When involving polymers in the manufacturing of composites, several factors must be considered, such as polymer hydration, breaking of monomer-bonds, polymer degradation, and diffusion of the solutions used. Consideration of the hydroxyapatite composition is needed to facilitate the filtration of water into the composite matrix [49]. Ganesan et al. (2019) conducted research on eggshell-based hydroxyapatite and the weight loss that occurred [27]. The process of in vitro degradation of the hydroxyapatite material for 28 days resulted in a weight loss that was less than $3 \%$. This occurred because the sintering temperature was too high; thus, the hydroxyapatite changed into a secondary phase, namely $\beta$-TCP. This secondary phase caused the rate of the material weight loss to slow [27].

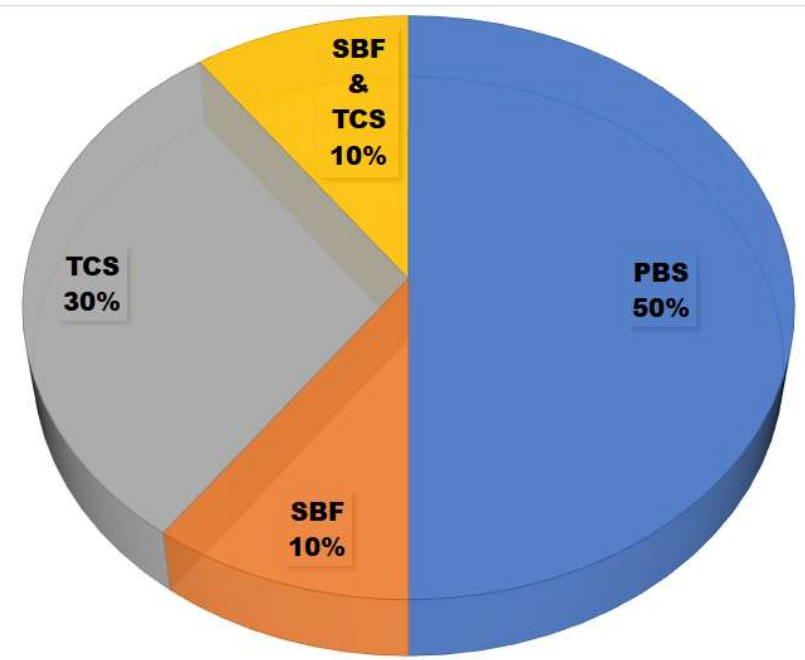

Figure 5. Solutions used for in vitro degradation tests to determine the weight loss of eggshell-based hydroxyapatite. 
The addition of other elements to hydroxyapatite as a composite does not always reduce the weight loss of the material. The weight loss that occurred in the eggshell-based hydroxyapatite indicates these would be adsorbed in the human body. When adding selenite to hydroxyapatite, the material loses a significant amount of weight because selenite ions are released during the in vitro degradation. Increasing the amount of selenite in the composition also increases weight loss [43]. The addition of rice husk ash (RHA), which produces the element wollastonite, causes high weight loss. Weight loss that is too high causes the $\mathrm{pH}$ to be high as well, thus limiting clinical applications [28]. It is necessary to add other elements that are safe for medical applications to stabilize the weight loss of hydroxyapatite-wollastonite composites, including zirconia (Zr) [31] and argentum (Ag) [30], as well as the selection of the solutions used [35]. With the same soaking time and solution, zirconia is able to reduce the weight loss of materials. Furthermore, the use of the SBF solution can also reduce the weight loss of the material because hydroxyapatite settles on the surface of the SBF solution [28].

The degradation rate is related to the bioactivity of the material [29]. The degradation process is affected by several factors, such as powder crystallinity, grain size, microstructure, and the surface area of the material [31]. Connectivity between the grains also affects the process of material degradation [29]. The main phase of hydroxyapatite shows a high degradation rate [27]. Eggshell-based hydroxyapatite has a higher weight loss with a smaller crystal size. The ions produced from the eggshell also affect the weight loss of the materials [33]. It is not possible to stimulate cellular proliferation if low ionic concentrations result from very slow dissolution rates [28]. The $\mathrm{pH}$ of the medium increases for up to 7 days due to the release of $\mathrm{OH}$ ions from the samples by dissolution in the soaking medium. Subsequently, the $\mathrm{pH}$ value decreases, which may be assumed to be due to the deposition of apatite that consumes $\mathrm{OH}$ ions. Sundaram et al. conducted an experiment that showed eggshell-based hydroxyapatite prepared with polycaprolactone (PCL) nanocomposite film had a larger weight loss than other materials. This organic-inorganic composite was found to be suitable for bone tissue engineering [35].

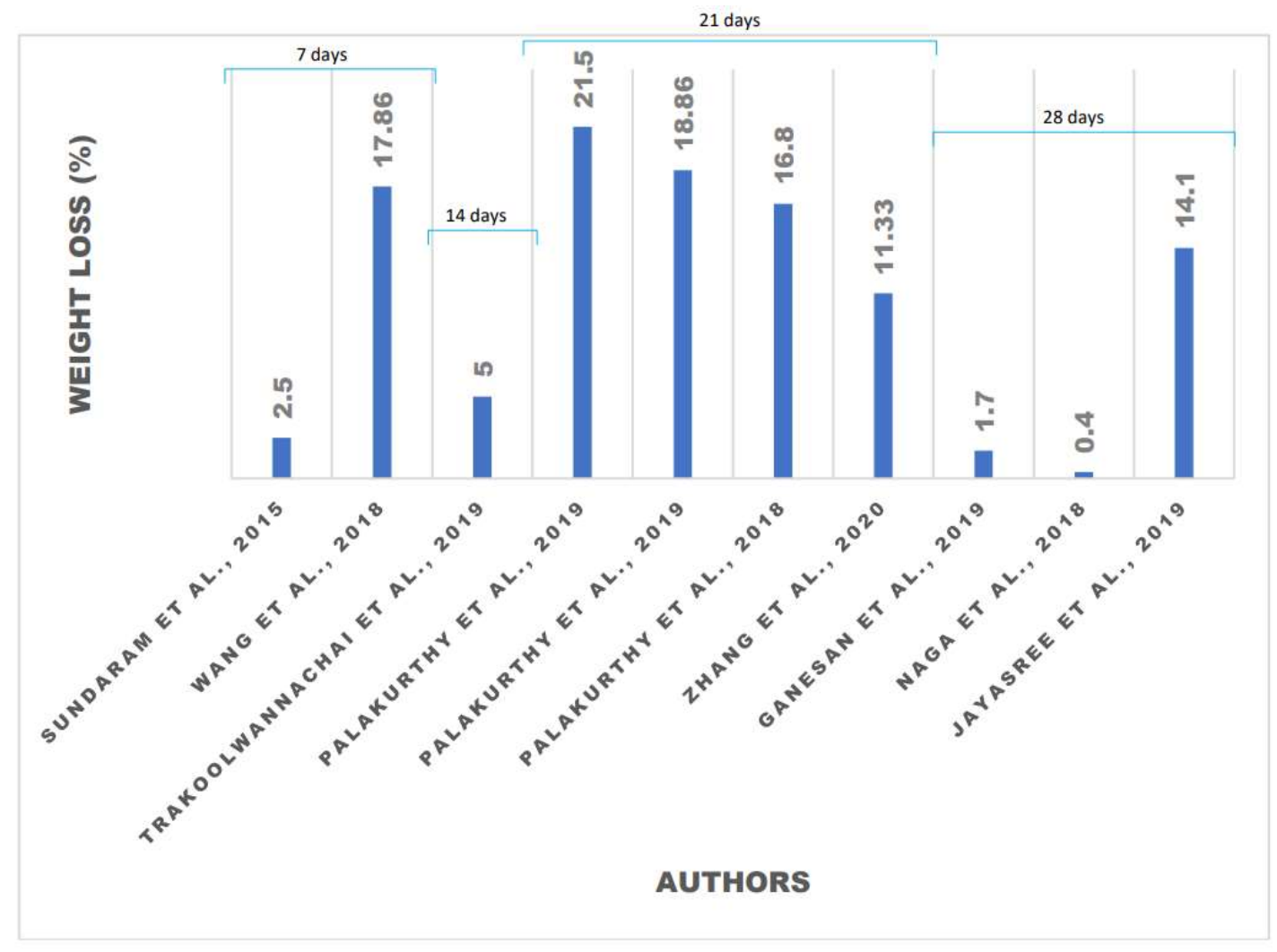

Figure 6. Weight loss of the eggshell-based hydroxyapatite after soaking for various times. 
In vitro cell culture testing provides information on the biocompatibility of the material [11]. There are two types of stem cells used for cultured in cytotoxicity test by optical density results, i.e. stem cells from humans $[2,49,50]$, shown in Table 3, and stem cells from animals [11], shown in Table 4. Using cell culture methods can also stimulate cell proliferation [2]. The stem cells are usually used as permanent cells because they are similar to human bone osteoblasts [49]. If the optical density increases, the surface area also increases for cell adhesions. Cell adhesions provide advantages for growth and cell viability [50]. Materials that use eggshell-based hydroxyapatite have good optical density results because the absorbance for all porous scaffolds higher than control due to the high surface area determined by the porous morphology and the bioactive properties of calcium phosphate [2]. As shown in Figure 4, it was found that the material culture in stem cells does not cause cytotoxicity.

Materials for bone tissue engineering applications must be used without provoking any immune response in the human body [45]. Cell toxicity is one of the challenges related to the application of bone tissue engineering and the manufacturing of new biomaterials [14]. Cytotoxicity testing is used to determine metabolic function and cell health in the bone tissue environment [26]. One of the factors measured with cytotoxicity testing is cell viability. Viable cells are used to examine cell responses and determine the interactions between the cells in biomaterials [54]. Viable cells were shown as a percentage comparison for the value of optical density treatment and optical density control from eggshell-based hydroxyapatite. The interactions between cells and samples have an effect on growth and differentiate cells that affect bone growth [65]. Furthermore, cell attachment is an early indicator of the interaction between cell proliferation and cell differentiation [54].

$$
\text { Viability Cells }=\frac{[\text { OD test }]}{[\text { OD control }]} \times 100 \%
$$

ISO 10993-5:2009 states that for in vitro cytotoxicity testing, if the percentage of viable cells is greater than $70 \%$ in the control group for the minimum concentration, the material is considered noncytotoxic [31]. It means that there should not be a decrease of viable cells of more than $30 \%$ [26]. In the analysis of the studies we conducted, the cultured cells came from humans and animals, including mice [27,35,40], rats [25,33,36], and monkeys [41,42]. As shown in Tables 3 and 4, with the varieties of cell cultures used, all studies obtained viable cell results of more than $70 \%$ with a variety of materials, either pure eggshell-based hydroxyapatite or composites of eggshell-based hydroxyapatite and other materials.

The addition of $\mathrm{Si}$ and $\mathrm{Mg}$ to the hydroxyapatite composite can increase the viability and proliferation of cells in osteoblasts [55]. Yilmaz et al. [47] also tested HA/CS/GO composites, in which the addition of graphite was shown to increase the osteoconductivity of the materials. In addition, zirconia [31] and wollastonite compounds obtained from rice husk ash also did not have a biological cell toxicity effect [30]. In eggshell-based hydroxyapatite cement, viable cells reached about $110 \%$, and the cell culture adhered to and spread on the sample surface because eggshell-based cement had smaller and densely packed crystals causing initial high compressive strength [33]. Egg white protein, which acts as a hydrogel, has benefits for osteogenic differentiation cells and increases bone regeneration when mixed with eggshells as hydroxyapatite [64]. Eggshell results in cell viability decreasing by less than $5 \%$ because $\mathrm{CaO}$ as a constituent of eggshell-based hydroxyapatite has high cytotoxicity [41].

Viable cells are affected by a few indicators, such as the sintering temperature [41], composition and size of the particles [45], morphology, porosity, and surface energy [35]. The sintering temperature affects the particle size and crystallinity of the material, where a higher sintering temperature is proportional to the crystallinity of the particles [41]. Viable cells decrease when heating the material to a higher temperature [25]. Cell activity and improved calcium release also occur in materials with low crystallinity [54]. As shown in Table 4, among the different calcium carbonate sources, eggshell-derived hydroxyapatite promotes the best cell adhesion and proliferation, which are comparable with those of pure 
hydroxyapatite but without the formation of clusters [51]. Compared with fish bones, fish scales, cuttlefish bone, and synthetic calcium carbonate, eggshell-based hydroxyapatite showed improved cell survival rate, because eggshell contains calcium oxide $(\mathrm{CaO})$, which has high cytotoxicity [41]. Cuttlefish bone and synthetic calcium carbonate with round grains have poor cell adhesions [51]. However, in general, hydroxyapatite, which is made from various materials, showed biocompatibility and their application as implants for bone regeneration [36]. The use of eggshells as a raw material can sufficiently reduce processing costs [26].

In this work, several tests regarding the biocompatibility of eggshell-based hydroxyapatite have been summarized in the last ten years. The result of in vitro degradation and cytotoxicity tests are displayed by meta-analysis in the tables and figures; these contain the weight loss of eggshell-based hydroxyapatite, optical density, and the viability of cells using stem cells from human and animals. There is still need for further clinical research to ensure the biocompatibility of eggshell-based hydroxyapatite and its use in bone tissue engineering.

\section{Conclusions}

This literature review summarized the reported biocompatibility of eggshell-based hydroxyapatite by focusing on two aspects: in vitro degradation and cytotoxicity tests from various studies. Eggshell-based hydroxyapatite is an alternative biomaterial that can be useful for reducing natural waste. Biological testing is needed to determine the biocompatibility of implant materials. The results of in vitro degradation and cytotoxicity tests have proven that materials that use eggshells to formulate hydroxyapatite have significant biocompatibility. There can be a decrease in the weight loss of the material when soaking in solutions with the same $\mathrm{pH}$ stability as the human body, together with an appropriate cell response when the material is cultured with stem cells that have a similar structure to human bone. Continued research to ensure the biocompatibility of eggshell-based hydroxyapatite and its use as a candidate for bone tissue engineering can be a further opportunity for meta-analysis.

Author Contributions: Conceptualization, R.R., W.H., U.U. and P.U.; methodology, W.H. and U.U.; software, R.R. and W.H.; validation, U.U., J.T. and K.D.; formal analysis, U.U., J.T. and K.D.; investigation, R.R., W.H. and U.U.; resources, R.R., W.H. and P.U.; data curation, R. and W.H.; writing-original draft preparation, R.R. and W.H.; writing-review and editing, U.U., J.T., K.D. and P.U.; visualization, R.R. and W.H.; supervision, U.U., J.T. and K.D.; project administration, U.; funding acquisition, R.R. and U.U. All authors have read and agreed to the published version of the manuscript.

Funding: Authors thank the Universitas Sebelas Maret for supporting financial aids in 2021-2022 through Hibah non APBN. We also appreciate Loka Pengaman Fasilitas Kesehatan (LPFK), Surakarta, Indonesia for the partial research funding.

Institutional Review Board Statement: Not applicable.

Informed Consent Statement: Not applicable.

Data Availability Statement: The data presented in this study are available from the corresponding author.

Conflicts of Interest: The authors declare no conflict of interest.

\section{References}

1. Akram, M.; Ahmed, R.; Shakir, I.; Ibrahim, W.A.W.; Hussain, R. Extracting hydroxyapatite and its precursors from natural resources. J. Mater. Sci. 2013, 49, 1461-1475. [CrossRef]

2. Neacsu, I.A.; Serban, A.P.; Nicoara, A.I.; Trusca, R.; Ene, V.L.; Iordache, F. Biomimetic Composite Scaffold Based on Naturally Derived Biomaterials. Polymers 2020, 12, 1161. [CrossRef]

3. Su, Y.; Champagne, S.; Trenggono, A.; Tolouei, R.; Mantovani, D.; Hermawan, H. Development and characterization of silver containing calcium phosphate coatings on pure iron foam intended for bone scaffold applications. Mater. Des. 2018, 148, 124-134. [CrossRef] 
4. Sopyan, I.; Sulaiman, N.S.; Gustiono, D.; Herdianto, N. Porous hydroxyapatite-gelatin composites with functions of bone substitutes and drug releasing agents: A preliminary study. In BioMEMS and Nanotechnology II; SPIE: Bellingham, WA, USA, 2005; Volume 6036, p. 60360C. [CrossRef]

5. Aminzare, M.; Eskandari, A.; Baroonian, M.; Berenov, A.; Hesabi, Z.R.; Taheri, M.; Sadrnezhaad, S. Hydroxyapatite nanocomposites: Synthesis, sintering and mechanical properties. Ceram. Int. 2013, 39, 2197-2206. [CrossRef]

6. Afriani, F.; Siswoyo; Amelia, R.; Hudatwi, M.; Zaitun; Tiandho, Y. Hydroxyapatite from natural sources: Methods and its characteristics. IOP Conf. Ser. Earth Environ. Sci. 2020, 599, 12055. [CrossRef]

7. Gergely, G.; Wéber, F.; Lukács, I.; Tóth, A.L.; Horváth, Z.E.; Mihály, J.; Balázsi, C. Preparation and characterization of hydroxyapatite from eggshell. Ceram. Int. 2010, 36, 803-806. [CrossRef]

8. Hart, A. Mini-review of waste shell-derived materials' applications. Waste Manag. Res. 2020, 38, 514-527. [CrossRef]

9. Sani, S.; Muljani, S.; Astuti, D.; Mardayana, R.; Alfiyani, V.D. Synthesis of Tricalcium Phosphate from Eggshells with Precipitation Method. J. Phys. Conf. Ser. 2020, 1569, 042057. [CrossRef]

10. Wu, S.-C.; Tsou, H.-K.; Hsu, H.-C.; Hsu, S.-K.; Liou, S.-P.; Ho, W.-F. A hydrothermal synthesis of eggshell and fruit waste extract to produce nanosized hydroxyapatite. Ceram. Int. 2013, 39, 8183-8188. [CrossRef]

11. Kumar, G.S.; Thamizhavel, A.; Girija, E. Microwave conversion of eggshells into flower-like hydroxyapatite nanostructure for biomedical applications. Mater. Lett. 2012, 76, 198-200. [CrossRef]

12. Das Lala, S.; Deb, P.; Barua, E.; Deoghare, A.; Chatterjee, S. Characterization of hydroxyapatite derived from eggshells for medical implants. Mater. Today Proc. 2019, 15, 323-327. [CrossRef]

13. Ho, W.-F.; Hsu, H.-C.; Hsu, S.-K.; Hung, C.-W.; Wu, S.-C. Calcium phosphate bioceramics synthesized from eggshell powders through a solid state reaction. Ceram. Int. 2013, 39, 6467-6473. [CrossRef]

14. Ingole, V.H.; Hussein, K.H.; Kashale, A.A.; Gattu, K.; Dhanayat, S.S.; Vinchurkar, A.; Chang, J.-Y.; Ghule, A.V. Invitro Bioactivity and Osteogenic Activity Study of Solid State Synthesized Nano-Hydroxyapatite using Recycled Eggshell Bio-waste. ChemistrySelect 2016, 1, 3901-3908. [CrossRef]

15. Sanosh, K.; Chu, M.-C.; Balakrishnan, A.; Kim, T.; Cho, S.-J. Utilization of biowaste eggshells to synthesize nanocrystalline hydroxyapatite powders. Mater. Lett. 2009, 63, 2100-2102. [CrossRef]

16. Viana, T.; Biscaia, S.; Bártolo, P.J. PCL/Eggshell Scaffolds for Bone Regeneration. In Proceedings of the ASME 201412 th Biennal Conference on Engineering Systems Design and Analysis ESDA2014-20213, Copenhagen, Denmark, 25-27 June 2014; pp. 1-6.

17. Kumar, T.S.; Madhumathi, K.; Rajkamal, B.; Zaheatha, S.; Malar, A.R.; Bai, S.A. Enhanced protein delivery by multi-ion containing eggshell derived apatitic-alginate composite nanocarriers. Colloids Surf. B Biointerfaces 2014, 123, 542-548. [CrossRef]

18. Noviyanti, A.R.; Rahayu, I.; Fauzia, R.P.; Risdiana. The effect of Mg concentration to mechanical strength of hydroxyapatite derived from eggshell. Arab. J. Chem. 2021, 14, 103032. [CrossRef]

19. Ain, Q.-U.; Munir, H.; Jelani, F.; Anjum, F.; Bilal, M. Antibacterial potential of biomaterial derived nanoparticles for drug delivery application. Mater. Res. Express 2019, 6, 125426. [CrossRef]

20. Kumar, G.S.; Girija, E. Flower-like hydroxyapatite nanostructure obtained from eggshell: A candidate for biomedical applications. Ceram. Int. 2013, 39, 8293-8299. [CrossRef]

21. Lin, K.; Chen, L.; Chang, J. Fabrication of Dense Hydroxyapatite Nanobioceramics with Enhanced Mechanical Properties via Two-Step Sintering Process. Int. J. Appl. Ceram. Technol. 2011, 9, 479-485. [CrossRef]

22. Ramesh, S.; Aw, K.; Tolouei, R.; Amiriyan, M.; Tan, C.; Hamdi, M.; Purbolaksono, J.; Hassan, M.; Teng, W. Sintering properties of hydroxyapatite powders prepared using different methods. Ceram. Int. 2013, 39, 111-119. [CrossRef]

23. Ressler, A.; Gudelj, A.; Zadro, K.; Antunović, M.; Cvetnić, M.; Ivanković, M.; Ivanković, H. From Bio-waste to Bone Substitute: Synthesis of Biomimetic Hydroxyapatite and Its Use in Chitosan-based Composite Scaffold Preparation. Chem. Biochem. Eng. Q. 2020, 34, 59-71. [CrossRef]

24. Tecu, C.; Antoniac, I.; Goller, G.; Yavas, B.; Gheorghe, D.; Antoniac, A.; Ciuca, I.; Semenescu, A.; Raiciu, A.D.; Cristescu, I. The Sintering Behaviour and Mechanical Properties of Hydroxyapatite-Based Composites for Bone Tissue Regeneration. Mater. Plast. 2019, 56, 644-648. [CrossRef]

25. Li, Y.; Wang, Y.; Li, Y.; Luo, W.; Jiang, J.; Zhao, J.; Liu, C. Controllable Synthesis of Biomimetic Hydroxyapatite Nanorods with High Osteogenic Bioactivity. ACS Biomater. Sci. Eng. 2019, 6, 320-328. [CrossRef] [PubMed]

26. Horta, M.K.D.S.; Moura, F.J.; Aguilar, M.S.; Westin, C.B.; De Campos, J.B.; Peripolli, S.B.; Ramos, V.S.; Navarro, M.I.; Archanjo, B.S. Nanostructured Hydroxyapatite from Hen's Eggshells Using Sucrose as a Template. Mater. Res. 2020, 23. [CrossRef]

27. Ganesan, V.; Devaraj, M.; Govindan, S.K.; Kattimani, V.; Kreedapathy, G.E.; Vivekanand, S.K.; Girija, E.K. Eggshell derived mesoporous biphasic calcium phosphate for biomedical applications using rapid thermal processing. Int. J. Appl. Ceram. Technol. 2019, 16, 1932-1943. [CrossRef]

28. Palakurthy, S.; Reddy, V.G.K.; Samudrala, R.K.; Azeem, A.P. In vitro bioactivity and degradation behaviour of $\beta$-wollastonite derived from natural waste. Mater. Sci. Eng. C 2018, 98, 109-117. [CrossRef]

29. Palakurthy, S.; Azeem, P.A.; Reddy, K.V.; Penugurti, V.; Manavathi, B. A comparative study on in vitro behavior of calcium silicate ceramics synthesized from biowaste resources. J. Am. Ceram. Soc. 2019, 103, 933-943. [CrossRef]

30. Palakurthy, S.; Abdul, A.P.; Venugopal, R.K. In vitro evaluation of silver doped wollastonite synthesized from natural waste for biomedical applications. Ceram. Int. 2019, 45, 25044-25051. [CrossRef] 
31. Superposition of Intra- and Inter-Layer Excitons in Twistronic MoSe2/WSe2 Bilayers Probed by Resonant Raman Scattering. Available online: https://iopscience.iop.org/article/10.1088/2053-1583/abe778 (accessed on 22 March 2021).

32. Roopavath, U.K.; Sah, M.K.; Panigrahi, B.B.; Rath, S.N. Mechanochemically synthesized phase stable and biocompatible $\beta$ tricalcium phosphate from avian eggshell for the development of tissue ingrowth system. Ceram. Int. 2019, 45, 12910-12919. [CrossRef]

33. Jayasree, R.; Kumar, T.S.S.; Venkateswari, R.; Nankar, R.P.; Doble, M. Eggshell derived brushite bone cement with minimal inflammatory response and higher osteoconductive potential. J. Mater. Sci. Mater. Med. 2019, 30, 113. [CrossRef]

34. Mondal, S.; Bardhan, R.; Mondal, B.; Dey, A.; Mukhopadhyay, S.S.; Roy, S.; Guha, R.; Roy, K. Synthesis, characterization and in vitro cytotoxicity assessment of hydroxyapatite from different bioresources for tissue engineering application. Bull. Mater. Sci. 2012, 35, 683-691. [CrossRef]

35. Sundaram, N.M.; Rajendran, N. Biodegradation and cytotoxicity of ciprofloxacin-loaded hydroxyapatite-polycaprolactone nanocomposite film for sustainable bone implants. Int. J. Nanomed. 2015, 10, 119-127. [CrossRef] [PubMed]

36. Ingole, V.H.; Hany Hussein, K.; Kashale, A.A.; Ghule, K.; Vuherer, T.; Kokol, V.; Chang, J.Y.; Ling, Y.C.; Vinchurkar, A.; Dhakal, H.N.; et al. Ultrasound Assisted Green Economic Synthesis of Hydroxyapatite Nanoparticles using Eggshell Biowaste and Study of Mechanical and Biological Properties for Orthopaedic Applications. J. Biomed. Mater. Res. Part A 2017, 105, 2935-2947. [CrossRef] [PubMed]

37. Ingole, V.H.; Vuherer, T.; Maver, U.; Vinchurkar, A.; Ghule, A.V.; Kokol, V. Mechanical Properties and Cytotoxicity of Differently Structured Nanocellulose-hydroxyapatite Based Composites for Bone Regeneration Application. Nanomaterials 2019, 10, 25. [CrossRef]

38. Choudhary, R.; Vecstaudza, J.; Krishnamurithy, G.; Raghavendran, H.R.B.; Murali, M.R.; Kamarul, T.; Swamiappan, S.; Locs, J. In-vitro bioactivity, biocompatibility and dissolution studies of diopside prepared from biowaste by using sol-gel combustion method. Mater. Sci. Eng. C 2016, 68, 89-100. [CrossRef]

39. Kattimani, V.S.; Chakravarthi, P.S.; Kanumuru, N.R.; Subbarao, V.V.; Sidharthan, A.; Kumar, T.S.S.; Prasad, L.K. Eggshell Derived Hydroxyapatite as Bone Graft Substitute in the Healing of Maxillary Cystic Bone Defects: A Preliminary Report. J. Int. Oral Health 2014, 6, 15-19. [PubMed]

40. Muthu, D.; Kumar, G.S.; Kattimani, V.; Viswabaskaran, V.; Girija, E. Optimization of a lab scale and pilot scale conversion of eggshell biowaste into hydroxyapatite using microwave reactor. Ceram. Int. 2020, 46, 25024-25034. [CrossRef]

41. Jahangir, M.U.; Islam, F.; Wong, S.Y.; Jahan, R.A.; Matin, A.; Li, X.; Arafat, M.T. Comparative analysis and antibacterial properties of thermally sintered apatites with varied processing conditions. J. Am. Ceram. Soc. 2021, 104, 1023-1039. [CrossRef]

42. Sultana, S.; Hossain, S.; Mahmud, M.; Bin Mobarak, M.; Kabir, H.; Sharmin, N.; Ahmed, S. UV-assisted synthesis of hydroxyapatite from eggshells at ambient temperature: Cytotoxicity, drug delivery and bioactivity. RSC Adv. 2021, 11, 3686-3694. [CrossRef]

43. Wang, Y.; He, W.; Hao, H.; Wu, J.; Qin, N. Eggshell derived Se-doped HA nanorods for enhanced antitumor effect and curcumin delivery. J. Sol-Gel Sci. Technol. 2018, 87, 600-607. [CrossRef]

44. Patel, D.K.; Jin, B.; Dutta, S.D.; Lim, K. Osteogenic potential of human mesenchymal stem cells on eggshells-derived hydroxyapatite nanoparticles for tissue engineering. J. Biomed. Mater. Res. Part B Appl. Biomater. 2019, 108, 1953-1960. [CrossRef]

45. Patel, D.K.; Kim, M.-H.; Lim, K.-T. Synthesis and Characterization of Eggshell-Derived Hydroxyapatite Bioceramics. J. Biosyst. Eng. 2019, 44, 128-133. [CrossRef]

46. Arslan, Y.E.; Arslan, T.S.; Derkus, B.; Emregul, E.; Emregul, K.C. Fabrication of human hair keratin/jellyfish collagen/eggshellderived hydroxyapatite osteoinductive biocomposite scaffolds for bone tissue engineering: From waste to regenerative medicine products. Colloids Surf. B Biointerfaces 2017, 154, 160-170. [CrossRef]

47. Yılmaz, P.; Çetiner, P.Y.; Bakırdere, S.; Ülgen, K.; Özbek, B. Application of supercritical gel drying method on fabrication of mechanically improved and biologically safe three-component scaffold composed of graphene oxide/chitosan/hydroxyapatite and characterization studies. J. Mater. Res. Technol. 2019, 8, 5201-5216. [CrossRef]

48. Oral, M.; Çalışkan, A.; Kapusuzc, D.; Ercan, B. Facile control of hydroxyapatite particle morphology by utilization of calcium carbonate templates at room temperature. Ceram. Int. 2020, 46, 21319-21327. [CrossRef]

49. Trakoolwannachai, V.; Kheolamai, P.; Ummartyotin, S. Characterization of hydroxyapatite from eggshell waste and polycaprolactone (PCL) composite for scaffold material. Compos. Part B: Eng. 2019, 173, 106974. [CrossRef]

50. Trakoolwannachai, V.; Kheolamai, P.; Ummartyotin, S. Development of hydroxyapatite from eggshell waste and a chitosan-based composite: In vitro behavior of human osteoblast-like cell (Saos-2) cultures. Int. J. Biol. Macromol. 2019, 134, 557-564. [CrossRef]

51. Cestari, F.; Agostinacchio, F.; Galotta, A.; Chemello, G.; Motta, A.; Sglavo, V. Nano-Hydroxyapatite Derived from Biogenic and Bioinspired Calcium Carbonates: Synthesis and In Vitro Bioactivity. Nanomaterials 2021, 11, 264. [CrossRef]

52. Hembrick-Holloman, V.; Samuel, T.; Mohammed, Z.; Jeelani, S.; Rangari, V.K. Ecofriendly production of bioactive tissue engineering scaffolds derived from egg- and sea-shells. J. Mater. Res. Technol. 2020, 9, 13729-13739. [CrossRef]

53. Nga, N.K.; Chau, N.T.T.; Viet, P.H. Facile synthesis of hydroxyapatite nanoparticles mimicking biological apatite from eggshells for bone-tissue engineering. Colloids Surf. B Biointerfaces 2018, 172, 769-778. [CrossRef]

54. Tram, N.X.T.; Ishikawa, K.; Minh, T.H.; Benson, D.; Tsuru, K. Characterization of carbonate apatite derived from chicken bone and its in-vitro evaluation using MC3T3-E1 cells. Mater. Res. Express 2021, 8, 25401. [CrossRef] 
55. Gutiérrez-Prieto, S.J.; Fonseca, L.F.; Sequeda-Castañeda, L.G.; Díaz, K.J.; Castañeda, L.Y.; Leyva-Rojas, J.A.; Salcedo-Reyes, J.C.; Acosta, A.P. Elaboration and Biocompatibility of an Eggshell-Derived Hydroxyapatite Material Modified with Si/PLGA for Bone Regeneration in Dentistry. Int. J. Dent. 2019, 2019, 1-12. [CrossRef] [PubMed]

56. Naga, S.M.; Sayed, M.; El-Maghraby, H.F.; Awaad, M. Investigation the impact of ZTA addition on the properties of nano biogenic hydroxyapatite. J. Mater. Sci. Mater. Electron. 2018, 29, 1-10. [CrossRef]

57. Adeogun, A.I.; Ofudje, A.E.; Idowu, M.A.; Kareem, S.O. Facile Development of Nano Size Calcium Hydroxyapatite Based Ceramic from Eggshells: Synthesis and Characterization. Waste Biomass-Valoriz. 2017, 9, 1469-1473. [CrossRef]

58. Hamidi, A.A.; Salimi, M.N.; Yusoff, A.H.M. Synthesis and characterization of eggshell-derived hydroxyapatite via mechanochemical method: A comparative study. AIP Conf. Proc. 2017, 1835, 020045. [CrossRef]

59. Prabakaran, K.; Balamurugan, A.; Rajeswari, S. Development of calcium phosphate based apatite from hen's eggshell. Bull. Mater. Sci. 2005, 28, 115-119. [CrossRef]

60. Malau, N.D.; Adinugraha, F. Synthesis of hydrokxyapatite based duck egg shells using precipitation method. J. Phy. Conf. Ser. 2020, 1563, 12020. [CrossRef]

61. Kamalanathan, P.; Ramesh, S.; Bang, L.; Niakan, A.; Tan, C.; Purbolaksono, J.; Chandran, H.; Teng, W. Synthesis and sintering of hydroxyapatite derived from eggshells as a calcium precursor. Ceram. Int. 2014, 40, 16349-16359. [CrossRef]

62. Farias, K.A.S.; Sousa, W.J.B.; Cardoso, M.J.B.; Lima, R.J.S.; Rodriguez, M.A.; Fook, M.V.L. Obtaining hydroxyapatite with different precursors for application as a biomaterial. Cerâmica 2019, 65, 99-106. [CrossRef]

63. Salerno, A.; Netti, P.A. Introduction to Biomedical Foams; Woodhead Publishing Limited: Sawston, UK, 2014.

64. Huang, K.; Hou, J.; Gu, Z.; Wu, J. Egg-White-/Eggshell-Based Biomimetic Hybrid Hydrogels for Bone Regeneration. ACS Biomater. Sci. Eng. 2019, 5, 5384-5391. [CrossRef]

65. Fang, I.J.; Trewyn, B.G. Application of Mesoporous Silica Nanoparticles in Intracellular Delivery of Molecules and Proteins, 1st ed.; Elsevier Inc.: Amsterdam, The Netherlands, 2012. 